\title{
ANALISIS FAKTOR YANG BERHUBUNGAN DENGAN STATUS GIZI BAYI USIA 6-12 BULAN PADA MASA PANDEMI COVID-19
}

\author{
Nur Afrinis ${ }^{1}$, Besti Verawati ${ }^{2}$, Any Tri Hendarini ${ }^{3}$ \\ Prodi S1 Gizi, FIK, Universitas Pahlawan Tuanku Tambusai ${ }^{1,2,3}$ \\ afrinis.eva@gmail.com ${ }^{1}$, bestiverawati@gmail.com²
}

\begin{abstract}
The condition of the Covid-19 pandemic can cause changes in social conditions and affect the nutritional status of infants. The research objective was to analyze the relationship between maternal knowledge, occupation and history of exclusive breastfeeding with the nutritional status of infants aged 6-12 months during the Covid 19 pandemic. This study was a quantitative study with a crosssectional design. The research samples were 62 mothers who had infants aged 6-12 months with total sampling technique. The research was conducted from January to March in Pulau Tinggi village, the working area of Puskesmas Kampar. The tools used are scales, and questionnaires. Data analysis used univariate and bivariate analysis with the chi square test. The results showed that as many as 45 mothers (72.58\%) lacked knowledge of mothers, 49 mothers $(79.03 \%)$ did not work, 33 infants (53.23\%) were given exclusive breastfeeding, and as many as 41 infants (66.1\%) ) abnormal nutritional status. Meanwhile, bivariate analysis showed a relationship between maternal knowledge $(p$-value $=0.001)$ and history of exclusive breastfeeding $(p$-value $=0.000)$, with the nutritional status of the infants. There was no relationship between maternal occupation and infant nutritional status ( -value $=0.058$.) There was a significant relationship between maternal knowledge and history of exclusive breastfeeding with infant nutritional status and there is no relationship between maternal occupation and maternal nutritional status. It was recommended that health workers provide counseling to mothers to increase knowledge about balanced nutrition in infants.
\end{abstract}

Keywords : Maternal Knowledge, History Of Exclusive Breastfeeding, Occupation, Nutritional Status Of Infants

\begin{abstract}
ABSTRAK
Kondisi Pandemi covid-19 dapat menyebabkan terjadinya perubahan kondisi sosial dan mempengaruhi status gizi bayi. Tujuan penelitian untuk menganalisis hubungan faktor pengetahuan ibu, pekerjaan dan riwayat pemberian ASI ekskusif dengan status gizi bayi usia 6-12 bulan pada masa pandemi covid 19. Penelitian ini merupakan penelitian kuantitatif dengan desain cross sectional. Sampel penelitian adalah 62 ibu yang mempunyai bayi usia 6-12 bulan dengan teknik total sampling. Penelitian dilakukan pada Januari- Maret di desa Pulau Tinggi wilayah kerja Puskesmas Kampar. Alat yang digunakan timbangan, dan kuesioner. Analisis data menggunakan analisa univariat dan bivariat dengan uji chi square. Hasil penelitian didapatkan bahwa sebanyak 45 ibu $(72,58 \%)$ pengetahuan ibu kurang, 49 ibu (79,03\%) tidak bekerja, sebanyak 33 bayi (53,23\%) diberikan ASI ekslusif, dan sebanyak 41 bayi $(66,1 \%)$ status gizinya tidak normal. Hasil analisis bivariat menunjukkan adanya hubungan pengetahuan ibu ( $\mathrm{p}$-value $=0.001)$ dan riwayat pemberian ASI eksklusif $(\mathrm{p}$-value $=0.000)$, dengan status gizi bayi. Tidak terdapat hubungan antara pekerjaan ibu dengan sttaus gizi bayi (pvalue $=0.058$.) Terdapat hubungan yang signifikan antara pengetahuan ibu dan riwayat pemberian ASI eksklusif dengan status gizi bayi dan tidak ada hubungan antara pekerjaan ibu dengan status gizi ibu. Disarankan kepda petugas kesehatan untuk memberikan penyuluhan kepada ibu untuk meningkatkan pengetahuan tentang gizi seimbang pada bayi.
\end{abstract}

Kata Kunci : Pengetahuan Ibu, Riwayat ASI Eksklusif, Pekerjaan, Status Gizi Bayi

\section{PENDAHULUAN}

Pandemi COVID-19 (corona virus) menyebabkan banyak perubahan dalam kehidupan sehari-hari, dimana hal ini akan berpengaruh terhadap status gizi. Usia bayi merupakan masa kritis pertumbuhan dan perkembangan yang pesat disertai dengan terjadinya penambahan kebutuhan zat gizi 
(Welasasih dan Wirjatmadi, 2012). Status gizi merupakan suatu keadaan yang menggambarkan kesehatan pada anak yang merupakan hasil interaksi antara makanan yang dikonsumsi dan pemanfaatannya oleh tubuh. Status gizi dapat diketahui salah satunya dengan metode antropometri yang terbagi menjadi dua jenis, yaitu pengukuran pertumbuhan (ukuran tubuh) dan pengukuran komposisi tubuh (Giri, 2013). Status gizi pada bayi dapat diukur berdasarkan data dari umur, berat badan, dan panjang badan (tinggi badan) (Kemenkes, 2014).

Penyebab masalah gizi dapat dipengaruhi oleh dua faktor utama yaitu faktor langsung dan faktor tidak langsung. Penyebab langsung yaitu faktor asupan makanan dan penyakit infeksi yang diderita. Faktor penyebab tidak langsung yaitu ketahanan pangan dalam keluarga, pola asuh, perawatan kesehatan dan sanitasi lingkungan yang kurang memadai. Keempat faktor tidak langsung tersebut saling berkaitan dengan pendidikan, pengetahuan, penghasilan, pekerjaan dan keterampilan ibu. Saat ini di dunia terdapat 3,5 juta kematian anak dibawah usia lima tahun yang disebabkan karena terjadinya masalah gizi. Dampak lain yang akan timbul adalah terganggunya pertumbuhan dan perkembangan mental, kecerdasan anak serta menyebabkan anak mudah terkena penyakit infeksi(Giri, 2013).

Faktor tidak langsung yang berkaitan dengan status gizi bayi yaitu pengetahuan ibu tentang gizi seimbang. Pengetahuan akan menentukan prilaku seseorang, secara rasional seorang ibu yang memiliki pengetahuan tinggi tentu akan berfikir lebih dalam bertindak, dia akan memperhatikan akibat yang akan diterima bila dia bertindak sembarangan, dalam menjaga kesehatan bayinya. Seorang ibu dituntut memiliki pengetahuan yang tinggi sehingga dapat memberikan makanan bergizi dan menjaga kesehatan bayinya.

Tingkat pengetahuan ibu tentang gizi sangat penting dalam meningkatkan status gizi keluarga terutama status gizi anaknya.
Hal ini dimulai dari menentukan, memilih, mengolah, sampai dengan menyajikan menu gizi sehari-hari ngetahuan gizi yang baik mendorong seseorang menjadi mampu merencanakan menu yang baik untuk dikonsumsi bagi keluarganya (Sediaoetama, 2018). Penelitian yang dilakukan Alfiana Tahun 2017 menyatakan bahwa ada hubungan antara pengetahuan ibu tentang gizi dengan status gizi anak (Alfiana, Meikawati, \& Ismail, 2017).

Selain pengetahuan ibu, faktor riwayat pemberian ASI eksklusif juga berhubungan dengan status gizi bayi. Air Susu Ibu (ASI) memiliki banyak manfaat bagi bayi. Pemberian ASI yang optimal merupakan kegiatan penting dalam pemeliharaan anak dan persiapan generasi penerus yang berkualitas di masa depan. Pertumbuhan dan perkembangan bayi dipengaruhi oleh jumlah zat gizi yang dikonsumsi. Kebutuhan zat gizi ini sebagian besar dapat terpenuhi dengan pemberian ASI yang cukup. ASI tidak hanya sebagai sumber energi utama tapi juga sebagai sumber protein, vitamin dan mineral utama bagi bayi. Pemberian ASI saja tanpa pemberian makanan atau minuman lain bisa mencukupi kebutuhan bayi sampai bayi berusia 6 bulan yang disebut dengan ASI eksklusif (Anggareni, 2017).

Air Susu Ibu (ASI) eksklusif berdasarkan Peraturan Pemerintah Nomor 33 Tahun 2012 adalah ASI yang diberikan kepada bayi sejak dilahirkan selama enam bulan, tanpa menambahkan dan/atau mengganti dengan makanan atau minuman lain (kecuali obat, vitamin, dan mineral). ASI mengandung kolostrum yang kaya akan antibodi karena mengandung protein untuk daya tahan tubuh dan pembunuh kuman dalam jumlah tinggi sehingga pemberian ASI eksklusif dapat mengurangi risiko kematian pada bayi. Penelitian yang dilakukan oleh Linawati \& Agustina Tahun 2019 menyatakan bahwa ada hubungan antara riwayat pemberian ASI eksklusif dengan status gizi bayi usia $7-24$ bulan.

Faktor pekerjaan juga berhubungan dengan status gizi bayi. Pekerjaan 
berhubungan dengan pendapatan merupakan faktor yang paling menentukan kualitas dan kuantitas makanan terdapat hubungan yang erat antara pendapatan yang meningkat untuk perbaikan kesehatan dan masalah keluarga yang berkaitan dengan keadaan gizi (Sulistyorini \& Rahayu, 2010)

Berdasarkan hasil data Riset Kesehatan Dasar (RISKESDAS) Tahun 2018, data gizi buruk dan gizi kurang pada bayi di Indonesia sebesar $17,7 \%$, sedangkan target Rencana Pembangunan Jangka Panjang Nasional (RPJMN) 2019 menyebutkan bahwa perbaikan status gizi masyarakat merupakan salah satu prioritas dengan menurunkan prevalensi gizi kurang menjadi 17\% (Kemenkes RI, 2019). Di Provinsi Riau data gizi buruk dan gizi kurang pada bayi tahun 2018 yaitu sebesar 18,2\%. Sedangkan di wilayah kerja Puskesmas Kampar dengan persentase sebesar 15,2\%. Desa Pulau Tinggi merupakan salah satu Desa diwilayah kerja Puskesmas Kampar dengan kasus gizi kurang dengan prevalensi $6,2 \%$.

Survei awal yang dilakukan peneliti di bulan Februari 2021 dengan melakukan wawancara, penimbangan bayi dan pengisian kuesioner pada 10 orang ibu yang memiliki bayi usia 6-12 bulan didapatkan data bahwa 6 bayi memiliki masalah status gizi terdiri dari 4 bayi mengalami status gizi kurang, 2 bayi status gizi lebih, dan 4 bayi lainnya memiliki status gizi normal. Sebanyak 8 ibu (80\%) pengetahuan gizi ibu rendah, dan $6 \mathrm{ibu}(60 \%)$ tidak bekerja. Oleh sebab itu, peneliti tertarik untuk melakukan penelitian mengenai faktor yang berhubungan dengan status gizi pada bayi usia 6-12 bulan.

Penelitian ini bertujuan untuk menganalisis hubungan faktor pengetahuan ibu, riwayat pemberian ASI eksklusif dan pekerjaan dengan status gizi bayi usia 6-12 bulan di Pulau Tinggi wilayah kerja Puskesmas Kampar tahun 2021.

\section{METODE}

Penelitian ini merupakan penelitian analitik dengan desain cross sectional.
Variabel independen penelitian ini adalah pengetahuan ibu tentang gizi seimbang pada bayi, riwayat pemberian ASI eksklusif dan pekerjaan ibu sedangkan variabel dependen adalah status gizi bayi usia $6-12$ bulan. Penelitian ini dilakukan di Desa Pulau Tinggi wilayah Puskesmas Kampar pada bulan Januari - Maret 2021. Populasi dalam penelitian ini adalah seluruh ibu dan bayi usia 6-12 bulan di Desa Pulau Tinggi wilayah kerja Puskesmas Kampar dengan jumlah 62 orang bayi. Sampel dalam penelitian ini yaitu ibu dan bayi usia 6-12 bulan di Desa Pulau Tinggi wilayah Puskesmas Kampar menggunakan teknik total sampling.

Alat yang digunakan pada penelitian ini adalah timbangan untuk mengukur berat badan bayi usia $6-12$ bulan, kuisioner untuk mengetahui pengetahuan gizi ibu, riwayat pemberian ASI eksklusif dan pekerjaan ibu. Pengukuran status gizi menggunakan timbangan untuk mengukur berat badan menggunakan indikator $\mathrm{BB} / \mathrm{U}$. Analisis data menggunakan analisa univariat dan bivariate dengan uji chi square.

\section{HASIL}

Berdasarkan karakteristik responden, usia bayi paling banyak terdapat pada usia 11 dan 12 bulan yaitu 13 bayi $(21,0 \%)$, berat badan bayi yang paling banyak terdapat pada berat 7-8 kg yang berjumlah 25 bayi (45\%) dan sebanyak 34 bayi $(54,8 \%)$ berjenis kelamin laki-laki. Hasil penelitian di Ghana menyebutkan bahwa anak perempuan memiliki resiko lebih besar mengalami masalah gizi dibandingkan dengan anak laki-laki (Eunice \& Sarah, 2013).

Hasil analisis univariat dalam penelitian ini adalah tingkat pengetahuan gizi ibu, riwayat pemberian ASI eksklusif, pekerjaan ibu dan status gizi bayi usia 6-12 bulan

\section{Analisa Univariat}

Untuk melihat distribusi tingkat pengetahuan gizi ibu, riwayat pemberian 
ASI eksklusif, pekerjaan ibu dan status gizi bayi usia 6-12 bulan dapat dilihat dari tabel dibawah ini:

Tabel 1. Distribusi tingkat pengetahuan ibu

\begin{tabular}{lcc}
\hline \multicolumn{1}{c}{ Tingkat Pengetahuan Ibu } & n & \% \\
\hline Kurang & 45 & 72.58 \\
Baik & 17 & 27.42 \\
\hline Total & 62 & 100 \\
\hline
\end{tabular}

Berdasarkan Tabel 1 dapat dilihat bahwa tingkat pengetahuan ibu yang memiliki bayi usia $6-12$ bulan sebagian besar berada pada kategori kurang yaitu sebanyak 45 orang (45\%).

Tabel 2. Distribusi riwayat pemberian ASI eksklusif

\begin{tabular}{|c|c|c|}
\hline Riwayat Pemberian ASI Ekslusif & $\mathbf{n}$ & $\%$ \\
\hline Tidak diberikan & 29 & 46.77 \\
\hline Ya diberikan & 33 & 53.23 \\
\hline Total & 62 & 100 \\
\hline
\end{tabular}

bahwa sebagian besar bayi memiliki riwayat diberikan ASI ekslusif sebanyak 33 bayi $(53.23 \%)$.

Sedangkan untuk variabel Pekerjaan iu berdasarkan tabel 3 dapat dilihat bahwa sebagian besar ibu bayi usia $6-12$ bulan tidak bekerja sebanyak $49 \mathrm{ibu}(79.03 \%)$.

Tabel 3. Distribusi pekerjaan ibu

\begin{tabular}{lcc}
\hline \multicolumn{1}{c}{ Pekerjaan } & $\mathrm{n}$ & $\boldsymbol{\%}$ \\
\hline Iya bekerja & 13 & 20.97 \\
Tidak bekerja & 49 & 79.03 \\
\hline Total & 62 & 100 \\
\hline \multicolumn{1}{c}{ Berdasarkan }
\end{tabular}

Berdasarkan tabel 4 dapat dilihat bahwa sebagian besar status gizi bayi usia 6 - 12 bulan tidak normal sebanyak 41 bayi $(66.1 \%)$ terdiri dari gizi kurang dan gemuk.

Tabel 4. Distribusi status gizi bayi usia 6 12 bulan

\begin{tabular}{lcc}
\hline \multicolumn{1}{c}{ Status Gizi } & n & $(\mathbf{\% )}$ \\
\hline Tidak Normal & 41 & 66.1 \\
Normal & 21 & 33.9 \\
\hline & $\mathbf{6 2}$ & $\mathbf{1 0 0}$ \\
\hline
\end{tabular}

\section{Analisa Bivariat}

Analisis bivariat dalam penelitian ini diperoleh dari data pengetahuan ibu tentang gizi, riwayat pemberian ASI ekslusif, dan pekerjaan ibu dihubungkan dengan status gizi bayi usia 6-12 bulan di Desa Pulau Tinggi wilayah kerja Puskesmas Kampar.

Tabel 5. Hubungan pengetahuan ibu tentang gizi dengan status gizi bayi usia $6-12$ bulan

\begin{tabular}{|c|c|c|c|c|c|c|c|}
\hline \multirow{3}{*}{ Tingkat Pengetahuan Ibu } & \multicolumn{4}{|c|}{ Status Gizi } & \multirow{2}{*}{\multicolumn{2}{|c|}{ Total }} & \multirow{3}{*}{$P$ value } \\
\hline & \multicolumn{2}{|c|}{ Tidak normal } & \multicolumn{2}{|c|}{ Normal } & & & \\
\hline & $\mathrm{n}$ & $\%$ & $\mathbf{n}$ & $\%$ & $\mathbf{n}$ & $\%$ & \\
\hline Kurang & 38 & 84.4 & 7 & 15.6 & 45 & 100 & \multirow{3}{*}{0.001} \\
\hline Baik & 3 & 17.6 & 14 & 82.4 & 17 & 100 & \\
\hline Total & 41 & 66.1 & 21 & 33.9 & 62 & 100 & \\
\hline $\begin{array}{l}\text { Berdasarkan Tabel } \\
\text { bahwa dari } 45 \text { ibu } \\
\text { pengetahuan kurang tent } \\
7 \text { bayi }(15.6 \%) \text { yang m } \\
\text { normal. Sedangkan dar } \\
\text { tingkat pengetahuan baik }\end{array}$ & $\begin{array}{l}\text { dap } \\
\text { nga }\end{array}$ & $\begin{array}{l}\text { dilihat } \\
\text { tingkat } \\
\text { banyak } \\
\text { us gizi } \\
\text { dengan } \\
3 \text { bayi }\end{array}$ & \multicolumn{5}{|c|}{$\begin{array}{l}\text { normal. Berdasarkan uji statistik chi square } \\
\text { diperoleh nilai } \mathrm{p} \text { value }=0.001(\mathrm{p}<0,05) \text {. } \\
\text { Ini berarti terdapat hubungan yang } \\
\text { signifikan antara tingkat pengetahuan ibu } \\
\text { tentang gizi dengan status gizi bayi usia } 6- \\
12 \text { bulan. }\end{array}$} \\
\hline
\end{tabular}

(17.6\%) yang mengalami status gizi tidak

Tabel 6. Hubungan riwayat pemberian ASI ekslusif dengan status gizi bayi usia 6 - 12 bulan

\begin{tabular}{|c|c|c|c|c|c|c|c|}
\hline \multirow{3}{*}{$\begin{array}{c}\text { Riwayat Pemberian ASI } \\
\text { Ekslusif }\end{array}$} & \multicolumn{4}{|c|}{ Status Gizi } & \multirow{2}{*}{\multicolumn{2}{|c|}{ Total }} & \multirow{3}{*}{$P$ value } \\
\hline & \multicolumn{2}{|c|}{ Tidak normal } & \multicolumn{2}{|c|}{ Normal } & & & \\
\hline & $\mathbf{n}$ & $\%$ & $\mathbf{n}$ & $\%$ & $\mathbf{n}$ & $\%$ & \\
\hline Iya & 25 & 46,5 & 18 & 41,9 & 43 & 100 & \multirow{2}{*}{0.000} \\
\hline Tidak & 16 & 52,6 & 3 & 15,8 & 19 & 100 & \\
\hline Total & 41 & 48,4 & 21 & 33,9 & 62 & 100 & \\
\hline
\end{tabular}


Sedangkan dari 19 bayi yang tidak diberikan ASI eksklusif, sebanyak 3 bayi (15.8\%) mengalami status gizi normal. Berdasarkan uji statistik chi square diperoleh nilai $p$ value $=0.000(p<0,05)$. Ini berarti terdapat hubungan yang signifikan antara riwayat pemberian ASI ekslusif dengan status gizi bayi usia $6-12$ bulan.

Tabel 7. Hubungan pekerjaan ibu dengan Status Gizi Bayi Usia 6-12 Bulan

\begin{tabular}{|c|c|c|c|c|c|c|c|}
\hline \multirow{3}{*}{ Pekerjaan Ibu } & \multicolumn{4}{|c|}{ Status Gizi } & \multirow{2}{*}{\multicolumn{2}{|c|}{ Total }} & \multirow{3}{*}{$P$ value } \\
\hline & \multicolumn{2}{|c|}{ Tidak normal } & \multicolumn{2}{|c|}{ Normal } & & & \\
\hline & $\mathbf{n}$ & $\%$ & $\mathbf{n}$ & $\%$ & $\mathbf{n}$ & $\%$ & \\
\hline Ya bekerja & 4 & 30.8 & 9 & 69.2 & 13 & 100 & \multirow{3}{*}{0.058} \\
\hline Tidak bekerja & 37 & 75.5 & 12 & 24.5 & 49 & 100 & \\
\hline Total & 41 & 66.1 & 21 & 33.9 & 62 & 100 & \\
\hline
\end{tabular}

Berdasarkan Tabel 7 dapat dilihat bahwa dari 13 ibu yang bekerja, sebanyak 4 ibu (30.8\%) memiliki bayi dengan status gizi tidak normal. Sedangkan dari 49 ibu yang tidak bekerja, sebanyak 12 ibu (15.8\%) mengalami bayi dengan status gizi normal. Berdasarkan uji statistik chi square diperoleh nilai $p$ value $=0.058(\mathrm{p}<0,05)$. Ini berarti terdapat tidak terdapat hubungan yang signifikan antara pekerjaan ibu dengan status gizi bayi usia $6-12$ bulan.

\section{PEMBAHASAN}

\section{Hubungan pengetahuan ibu tentang gizi dengan Status Gizi Bayi}

Berdasarkan hasil penelitian didapatkan bahwa dari 45 ibu dengan tingkat pengetahuan kurang tentang gizi, sebanyak 57 (15.6\%) ibu memiliki bayi dengan status gizi normal. Sedangkan dari $17 \mathrm{ibu}$ dengan tingkat pengetahuan baik, sebanyak 3 (17.6\%) ibu memiliki bayi dengan status gizi tidak normal. Berdasarkan uji statistik chi square diperoleh nilai $\mathrm{p}$ value $=0.001$ $(p<0,05)$. Ini berarti terdapat hubungan yang signifikan antara tingkat pengetahuan ibu tentang gizi dengan status gizi bayi usia $6-12$ bulan.

Pengetahuan ibu tentang gizi adalah segala sesuatu yang diketahui ibu tentang gizi. Pengetahuan akan menentukan perilaku ibu dalam bertindak (Notoatmodjo, 2014). Seorang ibu dituntut memiliki pengetahuan yang baik sehingga status gizi bayi juga normal.

Tingkat pengetahuan ibu tentang gizi sangat penting dalam meningkatkan status gizi anaknya. Menurut penelitian yang dilakukan (Alfiana et al., 2017) ibu sangat menentukan status gizi anaknya. Hal ini dimulai dari menentukan, memilih, mengolah, sampai dengan menyajikan menu gizi sehari-hari. Penelitian ini menyatakan bahwa ada hubungan antara pengetahuan ibu tentang gizi dengan status gizi anak (Alfiana et al., 2017).

\section{Hubungan riwayat pemberian ASI Eksklusif dengan Status Gizi Bayi}

Berdasarkan hubungan riwayat pemberian ASI eksklusif dan status gizi bayi didapatkan hasil bahwa dari 43 bayi yang diberikan ASI eksklusif, sebanyak 25 bayi $(46,5 \%)$ memiliki status gizi tidak normal. Sedangkan dari 19 bayi yang tidak diberikan ASI eksklusif, sebanyak 3 bayi (15.8\%) mengalami status gizi normal. Berdasarkan uji statistik chi square diperoleh nilai $\mathrm{p}$ value $=0.000(\mathrm{p}<0,05)$. Ini berarti terdapat hubungan yang signifikan antara riwayat pemberian ASI ekslusif dengan status gizi bayi usia 6 -12 bulan

ASI eksklusif memiliki kontribusi yang besar terhadap tumbuh kembang dan daya tahan tubuh bayi. Bayi yang diberi ASI eksklusif akan tumbuh dan berkembang secara optimal dan tidak mudah sakit (Afrinis, Indrawati, \& Haspriyanti, 2020).

\section{Hubungan pekerjaan ibu dengan Status Gizi Bayi}

Berdasarkan hubungan pekerjaan ibu dengan status gizi bayi didapatkan hasil bahwa dari 13 ibu yang bekerja, sebanyak 4 ibu $(30.8 \%)$ memiliki bayi dengan status 
gizi tidak normal. Sedangkan dari 49 ibu yang tidak bekerja, sebanyak 12 ibu (15.8\%) mengalami bayi dengan status gizi normal. Berdasarkan uji statistik chi square diperoleh nilai $\mathrm{p}$ value $=0.058(\mathrm{p}<0,05)$. Ini berarti terdapat tidak terdapat hubungan yang signifikan antara pekerjaan ibu dengan status gizi bayi usia 6 -12 bulan.

Pekerjaan merupakan mata pencaharian sehari-hari dari seseorang untuk mencari uang dalam memenuhi kebutuhan hidup sehari-hari. Pekerjaan memegang peranan besar terhadap penentuan status gizi bayi. Status pekerjaan ibu merupakan faktor yang bersifat memproteksi, artinya ibu yang tidak bekerja akan lebih mendukung dalam pemberian ASI ekslusif dibandingkan ibu yang bekerja sehingga akan berpengaruh terhadap status gizi bayi. Hal ini dikarenakan ibu yang tidak melakukan pekerjaan di luar rumah (IRT) akan memiliki banyak waktu dan kesempatan untuk menyusui bayinya dibandingkan dengan ibu yang bekerja di luar rumah (Sandika et al., 2020).

Faktor pekerjaan juga berhubungan dengan status gizi bayi. Pekerjaan berhubungan dengan pendapatan merupakan faktor yang paling menentukan kualitas dan kuantitas makanan terdapat hubungan yang erat antara pendapatan yang meningkat untuk perbaikan kesehatan dan masalah keluarga yang berkaitan dengan keadaan gizi.

\section{KESIMPULAN}

Berdasarkan penelitian didapatkan hasil pengetahuan ibu tentang gizi berada pada kategori kurang, Sebagian besar ibu bekerja, sebagian besar bayi diberikan ASI eksklusif dan satus gizi bayi tidak normal (kurus dan gemuk). Terdapat hubungan yang signifikan antara pengetahuan ibu tentang gizi dan riwayat pemberian ASI eksklusif dengan status gizi bayi usia 6-12 bulan di Desa Pulau Tinggi Wilayah kerja Puskesmas Kampar. Tidak terdapat hubungan antara pekerjaan ibu dengan status gizi bayi. Diharapkan kepada tenaga kesehatan untuk lebih giat memberikan penyuluhan tentang kesehatan dan gizi untuk meningkatkan pengetahuan ibu. Untuk orang tua untuk lebih memperhatikan konsumsi makanan anak dan kebersihan lingkungan.

\section{UCAPAN TERIMAKASIH}

Ucapan terima kasih terutama ditujukan kepada LPPM dan pihak Universitas Pahlawan Tuanku Tambusai yang telah memberikan dana untuk penelitian ini. Ucapan terima kasih juga kepada pihak Puskesmas Kampar dan responden yang membantu pelaksanaan penelitian.

\section{DAFTAR PUSTAKA}

Afrinis, N., Indrawati, \& Haspriyanti, N. (2020). Hubungan Pengetahuan Ibu tentang Manajemen Laktasi dan Dukungan Keluarga dengan Pemberian ASI Eksklusif pada Bayi Usia 0-6 Bulan. Prepotip Jurnal Kesehatan Masyarakat, 4(2), 157168.

https://doi.org/10.33024/jkm.v6i2.172 6

Alfiana, N., Meikawati, W., \& Ismail, T. S. (2017). Makanan Pendamping ASI dengan Status Gizi Anak (Studi di Kelurahan Manyaran Wilayah Kerja Puskesmas Manyaran Kota Semarang Tahun 2017 ) Fakultas Kesehatan Masyarakat Universitas Muhammadiyah Semarang Repository. Unimus. ac id Repository. Unimus. ac. 22.

Anggareni, D. (2017). Fast Food for Baby. Jakarta Selatan: Mitra Cendikia Press.

Eunice, A., \& Sarah, D. (2013). An Assessment of the Nutritional Status of under Five Children in Four Districts in the Central Region of Ghana. Asian Journal of Agricultural and Rural Development, 3(11), 851860 . 
Giri, M. K. W. (2013). Hubungan Pengetahuan dan Sikap Ibu tentang Pemberian ASI serta Pemberian ASI Eksklusif dengan Status Gizi Balita Usia 6-24 Bulan ( di Kelurahan Kampung Kajanan Kecamatan Buleleng). Jurnal Magister Kedokteran Keluarga, 1(1), 80-91.

Kemenkes, R. I. (n.d.). Riset kesehatan dasar RISKESDAS 2013. Indonesia: Kementrian Kesehatan RI.

Kemenkes RI. (2019). Profil Kesehatan Indonesia 2018 [Indonesia Health Profile 2018]. Retrieved from http://www.depkes.go.id/resources/do wnload/pusdatin/profil-kesehatanindonesia/Data-dan-Informasi_ProfilKesehatan-Indonesia-2018.pdf

Linawati, \& Agustina, H. (2019). Hubungan Pemberian ASI Eksklusif dengan Status Gizi Bayi 7-12 Bulan di Wilayah Kerja Puskesmas Kalianda Lampung Selatan. Manuju: Malahayati Nursing Journal, 3(2252), 58-66.

Notoatmodjo. (2014). Ilmu Perilaku Kesehatan. Jakarta: Rineka Cipta.

Sandika, P., Afrinis, N., \& Yahya, E. (2020). Hubungan Motivasi dan Pekerjaan Ibu dengan Pemberian Makanan Pendamping Air Susu Ibu (MP-ASI) Dini pada Bayi di Bawah Usia 6 Bulan. Jurnal Prepotif Universitas Pahlawan Tuanku Tambusai, 5(1), 263-270. https://doi.org/10.21460/bikdw.v4i1.1 45

Sediaoetama. (2018). Imu Gizi Untuk Mahasiswa dan Profesi Jilid I. Dian Rakyat. Jakarta.

Sulistyorini, E., \& Rahayu, T. (2010). Hubungan Pekerjaan Ibu Balita terhadap Status Gizi Balita di Posyandu Prima Sejahtera Desa Pandean Kecamatan Ngemplak Kabupaten Boyolali. Jurnal Kebidanan Indonesia, 1(2), 1-17. Retrieved from https://jurnal.stikesmus.ac.id/index.ph p/JKebIn/article/view/6
Welasasih, B. D., \& Wirjatmadi, R. B. (2012). Beberapa Faktor yang Berhubungan dengan Status Gizi Balita Stunting. The Indonesian Journal Of Public Health, 8(3), 99104. 